\title{
Surface Binding, Internalization and Degradation by Cultured Human Fibroblasts of Low Density Lipoproteins Isolated from Type 1 (Insulin-Dependent) Diabetic Patients: Changes with Metabolic Control
}

\author{
M. F. Lopes-Virella ${ }^{1}$, G. K. Sherer ${ }^{2 *}$, A. M. Lees ${ }^{4}$, H. Wohltmann ${ }^{3}$, R. Mayfield ${ }^{1}$, J. Sagel ${ }^{1}$, E. C. LeRoy ${ }^{2}$ \\ and J. A. Colwell' \\ Departments of Medicine, ('Endocrinology-Metabolism-Nutrition Division and ${ }^{2}$ Rheumatology Division) and \\ ${ }^{3}$ Pediatrics, Medical University of South Carolina, Charleston, and ${ }^{4}$ Arteriosclerosis Center, Massachusetts Institute of Technology, \\ Cambridge, Massachusetts, USA
}

\begin{abstract}
Summary. A previous study of low density lipoprotein metabolism by cultured cells focused on the metabolism of normal lipoproteins in vitro by fibroblasts isolated from diabetic patients. No abnormalities were found. We have followed the opposite approach. Using normal human fibroblasts as test cells we compared the metabolism in vitro of low density lipoproteins isolated from diabetic patients before and after metabolic control. We found a significant decrease $(p<0.02)$ in internalization and degradation of low density lipoproteins isolated from diabetic patients before metabolic control when compared with those isolated from normal control subjects or from the same patients after metabolic control. The observed changes were mainly apparent in intracellular degradation. To evaluate whether the observed differences in low density lipoprotein behaviour were correlated with lipid or apolipoprotein composition, we measured cholesterol, triglyceride, apolipoprotein $\mathrm{B}$ and total protein levels in the low density lipoproteins tested. A significant decrease $(p<0.05)$ of the triglyceride/protein ratio was found in post-control low density lipoproteins suggesting that a high triglyceride content may interfere with low density lipoprotein metabolism. The present study represents the first observation that metabolic control in diabetes mellitus can alter low density lipoprotein-cell interaction and suggests a possible mechanism for the enhanced incidence of atherosclerosis in diabetic patients.
\end{abstract}

Key words: Type 1 (insulin-dependent) diabetic patients, low density lipoprotein, pre-control LDL, postcontrol LDL; human fibroblasts, LDL uptake, LDL degradation, cell culture, LDL lipids, LDL apolipoprotein B, LDL-cell interaction.

* Present address: Department of Biology, Bowdoin College, Brunswick, Maine 04011, USA
There is an increased incidence of atherosclerosis in diabetes mellitus [1]. One feature common to both atherosclerosis and diabetes is the existence of hyperlipaemia. A postulated mechanism for the development of atherosclerosis in patients with hyperlipaemia was proposed by Goldstein and Brown [2]. These authors stated that the low density lipoprotein (LDL) pathway functions to protect against atherosclerosis by allowing cells to take up LDL to satisfy cholesterol needs and to maintain simultaneously plasma LDL concentration below threshold levels for atherosclerosis. If this mechanism would, indeed, be of biological significance, a decrease in the amount of LDL taken up and catabolized by the cells, either due to possible defects in the LDL pathway or to constitutional changes of the lipoprotein that could prevent its adequate uptake and/or intracellular metabolism, would eventually lead to the development of atherosclerosis.

The LDL pathway has been studied previously in fibroblasts isolated from diabetic patients by Chait et al. [3] and no abnormalities were found. We therefore decided to study the interaction between normal human fibroblasts and LDL isolated from insulin-dependent diabetic patients before and after strict metabolic control with insulin.

\section{Patients and Methods}

\section{Patients}

Sixteen Type 1 (insulin-dependent) diabetic patients (ten females and six males), ranging in age from 10 to 31 years were studied. Their weight varied within $10 \%$ of ideal body weight. Thirteen patients were hospitalized from 4 to 20 days (mean 11 days). They were all placed on a normocaloric diet, consisting of $20 \%$ calories as protein, $35 \%$ fat and $45 \%$ carbohydrate. An attempt was made to maintain these patients with a normal exercise level during the hos- 
pitalization period. Four patients were treated with a closed-loop insulin-delivery system (Biostator glucose controller, Miles Laboratories, Elkhart, Indiana) for 2 days followed by continuous SC insulin infusion administered by portable infusion pump (Model AS2C Autosyringe, Hookset, New Hampshire, USA). Nine patients were treated with short-acting insulin given SC four times daily. Twenty-four hour urinary glucose excretion was determined daily in all patients. Mean plasma glucose levels were obtained four times daily (fasting, before lunch and dinner and at midnight) during the first $48 \mathrm{~h}$ and in the 4 days preceding discharge in some patients and daily in others. Haemoglobin $\mathrm{A}_{1 \mathrm{c}}\left(\mathrm{HbA}_{\mathrm{ic}}\right)$ was measured in all patients on admission and at discharge. In all patients fasting blood samples were collected for lipoprotein studies within $24 \mathrm{~h}$ of admission and within $48 \mathrm{~h}$ of discharge.

The remaining three patients were only studied during a period of poor metabolic control. Fasting blood samples were collected in these three patients for lipoprotein studies and for glucose and $\mathrm{HbA}_{1 \mathrm{c}}$ determinations. Nine of the 16 patients were studied simultaneously with an age- and sex-matched control subject.

As control subjects we used 11 healthy volunteers (six females and five males) ranging in age from 16 to 30 years. In four of the normal control subjects blood was collected twice within 6-9 day intervals between bleeds. Informed consent, as approved by the Institutional Review Board for Human Research of the Medical University of South Carolina was obtained from all adult subjects involved in the study. Parental consent was obtained for minors.

\section{Cells}

Fibroblasts were obtained from pooled neonatal foreskins by enzymatic dissociation and sieving through nylon mesh as described previously [4]. Cultures were maintained on a mixture of medium F12K ( $85 \%)$ prepared as described [4] and fetal calf serum $(15 \%$; Sterile Systems, Logan, Utah, USA) buffered with N-2-hydroxyethyl piperazine $\mathrm{N}^{\prime}-2$ ethanesulphonic acid (HEPES) $(25 \mathrm{mmol} / 1$, $\mathrm{pH} 7.6$ ), in an atmosphere of $5 \% \mathrm{CO}_{2} / 95 \%$ air. Primary cultures were treated with penicillin $(50 \mathrm{U} / \mathrm{ml})$ and gentamicin $(50 \mu \mathrm{g} / \mathrm{ml})$, but antibiotics were withdrawn after the first passage and they were only added again at the beginning of each experiment.

Second-passage cells were stored by freezing in liquid nitrogen, and thereafter were thawed as needed. All experiments were performed in the third to eighth passage of the cells, using the same pool of fibroblast cells.

\section{Lipoprotein and Lipoprotein Deficient Serum}

Low density lipoprotein $(d>1.019,<1.063 \mathrm{~g} / \mathrm{ml})$ were isolated from plasma by sequential ultracentrifugation in a preparative ultracentrifuge (Beckman L5-50) after appropriate adjustment of density with solid $\mathrm{KBr}$ [5]. LDL preparations were washed by ultracentrifugation, stored under nitrogen, in the dark. Before labelling, the LDL were dialysed against a $0.15 \mathrm{~mol} / 1 \mathrm{NaCl}$ solution containing EDTA $1 \mathrm{mmol} / 1$ (pH 7.4). Each isolated LDL migrated as a homogenous peak on polyacrylamide gel lipoprotein electrophoresis [6]. LDL, passed through Acrodisc filter ( $0.2 \mu \mathrm{m}$ pore size) in order to remove aggregates, were iodinated with ${ }^{125} \mathrm{I}$ by the McFarlane procedure as modified by Bratzler et al. [7]. LDL isolated from each patient before and after metabolic control were iodinated simultaneously and studied in the same experiment.

The integrity of ${ }^{125} \mathrm{I}$-labelled LDL was assessed by incubating, in parallel, increasing concentrations of ${ }^{125} \mathrm{I}$-labelled LDL $\left(5-80 \mu \mathrm{g} / \mathrm{ml}\right.$ of medium) and ${ }^{125} \mathrm{I}-\mathrm{LDL}(5 \mu \mathrm{g} / \mathrm{ml})$ progressively diluted with unlabelled LDL to equal concentrations $(5-80 \mu \mathrm{g} / \mathrm{ml}$ medium). The same LDL preparation was used in its native form (unlabelled) and after ${ }^{125}$ I-labelling to perform these experiments. Binding, internalization and degradation of ${ }^{125} \mathrm{I}$-labelled LDL and ${ }^{125}$ I-labelled LDL diluted with unlabelled LDL were similar at all concentrations studied after an appropriate correction for the changes in specific activity due to dilution. Radioactivity localized in the lipid moiety of LDL was determined after a Folch lipid extraction [8] and ranged from $1.6 \%$ to $8 \%$ of the total radioactivity. No significant differences in the radioactivity of the lipid moieties of LDL were found between LDL isolated from diabetic subjects before metabolic control (4.8\%); after metabolic control (3.8\%) and from normal subjects $(3.4 \%)$

Lipoprotein deficient plasma was separated by ultracentrifugation after adjustment of density to $1.25 \mathrm{~g} / \mathrm{ml}$ with solid $\mathrm{KBr}$ [S]. After removal of the lipoproteins contained in the top fraction, the bottom fraction was recentrifuged, under the same conditions to ensure complete removal of lipoproteins. The plasma was clotted with thrombin using the method of Brown et al. [9] modified by the addition of calcium $(2.5 \mathrm{mg} / \mathrm{ml})$. It was then dialyzed against a $0.15 \mathrm{~mol} / 1 \mathrm{NaCl}$ solution ( $\mathrm{pH} 7.4$ ) and sterilized by filtration (Acrodisc filter, $0.45 \mu \mathrm{m}$ pore size) before use. Its total cholesterol content was below $60 \mathrm{ng} / \mathrm{mg}$ of protein.

\section{Binding, Internalization and Degradation of ${ }^{125} I-L D L$}

Five $\mathrm{X} 10^{5}$ cells were inoculated into $60 \mathrm{~mm}$ tissue culture dishes (Falcon Products, Cockeysville, Maryland, USA) in F12K medium containing $15 \%$ fetal calf serum, penicillin $(50 \mathrm{U} / \mathrm{ml})$ and gentami$\operatorname{cin}(50 \mu \mathrm{g} / \mathrm{ml})$. After incubation for $3-4$ days, the medium was removed, the cells were washed with Hank's balanced salt solution (HBSS) and fresh medium containing antibiotics and lipoprotein deficient serum $(2.5 \mathrm{mg}$ protein $/ \mathrm{ml}$ medium) was added $(2 \mathrm{ml} /$ dish). Twenty-four hours later, the medium was removed again and fresh medium with the same composition and containing ${ }^{125} \mathrm{I}-\mathrm{LDL}$ in three different concentrations $(10,20$ and $40 \mu \mathrm{g} / \mathrm{ml}$ of medium) was added. In each experiment LDL isolated from diabetic patients before and after metabolic control were studied. LDL from age- and sex matched normal subjects were tested simultaneously in seven of the experiments but only two concentrations (10 and $40 \mu \mathrm{g} \mathrm{LDL} / \mathrm{ml}$ medium) were used for the normal LDL in some of the experiments. Cultures were incubated for $18 \mathrm{~h}$, at $37^{\circ} \mathrm{C}$, in a humidified incubator equilibrated with $5 \% \mathrm{CO}_{2}$ in air. After incubation, the medium was removed, the cell layer was washed five times, two times with cold HBSS containing $2 \mathrm{mg} / \mathrm{ml}$ of bovine serum albumin, and three times with the same solution containing no bovine serum albumin. Afterwards the cell layer was treated for $5 \mathrm{~min}$ with a solution of $0.05 \%$ trypsin and $0.01 \%$ EDTA in $\mathrm{Ca}^{++}$and $\mathrm{Mg}^{++}$free HBSS. Cell pellets were obtained by centrifugation at $4^{\circ} \mathrm{C}, 2,500 \mathrm{rev} / \mathrm{min}$, for $45 \mathrm{~min}$. The amount of surface-bound and internalized LDL was calculated by dividing, respectively, the radioactivity released by trypsin (i.e. in the supernatant) and the radioactivity in the cell pellet by the specific activity of LDL. Duplicate determinations of ${ }^{125}$ I-LDL binding and internalization varied by less than $10 \%$ of the mean values. The medium removed before trypsin treatment was used to study degradation by the method of Bierman et al. [10]. Net degradation was calculated as the difference between values obtained from identical incubations in the presence and absence of cells. Duplicate determinations of ${ }^{125} \mathrm{I}$ LDL degradation varied by less than $5 \%$ of the mean values. All results were expressed as ng LDL/mg of cell protein. Protein was determined in the cell pellets by the method of Lowry et al. [11]. The cell pellets were solubilized overnight, at $4^{\circ} \mathrm{C}$, with $300 \mu 1$ of $1 \mathrm{~mol} / 1 \mathrm{KOH}$ and the final volume was adjusted to $1 \mathrm{ml}$ with $0.9 \%$ saline. The lipids contained in the cell pellets were extracted by the method of Folch et al. [8] and the radioactivity associated with it determined. As a rule the radioactivity contained in the lipid portion of the cell pellets was $2 \%-5 \%$ higher than that associated with the lipoprotein. The radioactivity associated with the lipid portion was subtracted from the surface binding and internalization values.

The above protocol was designed to study LDL behaviour under culture conditions that led to up-regulation of $L D L$ receptors. 
Table 1. Surface binding, internalization and degradation by normal human fibroblasts of LDL isolated from 13 diabetic patients before and after metabolic control

\begin{tabular}{|c|c|c|c|c|}
\hline & $\begin{array}{l}\text { Diabetic patients } \\
\text { before control }\end{array}$ & $\begin{array}{l}\text { Diabetic patients } \\
\text { after control }\end{array}$ & changes & $p$ \\
\hline \multicolumn{5}{|c|}{ Binding (ng LDL/mg cell protein) } \\
\hline $10 \mu \mathrm{g} \mathrm{LDL} / \mathrm{ml}$ medium & $181 \pm 17$ & $203 \pm 19$ & $21.3 \pm 11.4$ & NS \\
\hline $20 \mu \mathrm{g} \mathrm{LDL} / \mathrm{ml}$ medium & $300 \pm 31$ & $332 \pm 34$ & $32.2 \pm 22.3$ & NS \\
\hline $40 \mu \mathrm{g} \mathrm{LDL} / \mathrm{ml}$ medium & $440 \pm 46$ & $503 \pm 48$ & $62.3 \pm 32.5$ & NS \\
\hline \multicolumn{5}{|c|}{ Internalization (ng LDL/mg cell protein) } \\
\hline $10 \mu \mathrm{g} \mathrm{LDL} / \mathrm{ml}$ medium & $772 \pm 51$ & $906 \pm 50$ & $134 \pm 45$ & $<0.02$ \\
\hline $20 \mu \mathrm{g} \mathrm{LDL} / \mathrm{ml}$ medium & $1127 \pm 72$ & $1359 \pm 91$ & $232 \pm 68$ & $<0.01$ \\
\hline $40 \mu \mathrm{g} \mathrm{LDL} / \mathrm{ml}$ medium & $1749 \pm 128$ & $2064 \pm 132$ & $315 \pm 111$ & $<0.02$ \\
\hline \multicolumn{5}{|c|}{ Degradation (ng LDL/mg cell protein) } \\
\hline $10 \mu \mathrm{g} \mathrm{LDL} / \mathrm{ml}$ medium & $4096 \pm 505$ & $5461 \pm 497$ & $1364 \pm 437$ & $<0.01$ \\
\hline $20 \mu \mathrm{g} \mathrm{LDL} / \mathrm{ml}$ medium & $6178 \pm 788$ & $7752 \pm 696$ & $1574 \pm 529$ & $<0.02$ \\
\hline $40 \mu \mathrm{g} \mathrm{LDL} / \mathrm{ml}$ medium & $8162 \pm 842$ & $10527 \pm 921$ & $2366 \pm 781$ & $<0.02$ \\
\hline
\end{tabular}

Results expressed as mean $\pm \mathrm{SEM}$; NS $=$ not significant

In order to evaluate the LDL metabolism when LDL receptors were down-regulated, a modified protocol was used. After the initial cell growth of $3-4$ days in F12K medium containing $15 \%$ fetal calf serum and antibiotics, the cells were washed and fresh medium containing antibiotics, lipoprotein deficient serum $(2.5 \mathrm{mg}$ protein $/ \mathrm{ml}$ medium) and the unlabelled LDL to be studied $(100 \mu \mathrm{g} / \mathrm{ml}$ of medium) was added ( $2 \mathrm{ml} /$ dish).

Twenty-four hours later, the medium was removed, the cells washed and fresh medium containing ${ }^{125} \mathrm{I}-\mathrm{LDL}$ in two concentrations ( 10 and $40 \mu \mathrm{g} / \mathrm{ml}$ of medium) was added and the cultures were incubated for $18 \mathrm{~h}$, as described. The next steps of the protocol were similar to the ones already described for the study of LDL behaviour under conditions of up-regulation of LDL receptors.

LDL isolated from two diabetic patients in poor metabolic control and two sex- and age-matched normal subjects were studied simultaneously under culture conditions set for the study of LDL behaviour under up- and down-regulation of LDL receptors. In all of the experiments described above, each value represents the mean of duplicate incubations and measurements.

\section{Other Methods}

Plasma and $24 \mathrm{~h}$ urinary glucose was assayed using the glucose oxidase method as adapted for use in the Beckman glucose analyzer [12]. $\mathrm{HbA}_{1 \mathrm{c}}$ was measured by isoelectric focussing of erythrocyte haemolysates over a $\mathrm{pH}$ gradient of $6-8$, according to the method of Spicer et al. [13] with slight modifications.

Cholesterol and triglyceride levels were measured using the semi-automated method standardized by the Lipid Research Clinics Program [14]. Free and total cholesterol were assayed on a Sigma 3 gas-chromatograph equipped with a hydrogen flame ionization detector, using a glass column packed with $3 \% \mathrm{OV}-17$ on 100-120 mesh Supelcoport and $\mathrm{N}_{2}$ as the gas carrier. The column temperature was maintained at $280^{\circ} \mathrm{C}$ and the flow of the carrier gas was $40 \mathrm{ml} / \mathrm{min}$. LDL were extracted with chloroform: methanol $(2: 1)$ and washed according to the method of Folch et al. [8]. For the total cholesterol assay one aliquot of the washed chloroform phase was hydrolyzed by the method of Ishikawa et al. [15]. As internal standard, 5- $\alpha$-cholestane was used.

Apolipoprotein B levels were measured using a slightly modified version of Laurell's electro-immunodiffusion technique [16] similar to the one described by us for apolipoprotein AI [17]. Antiapo B antisera ( $1.5 \mathrm{ml} / \mathrm{I}$ of the Agarose/Dextran 10 solution) was used. LDL isolated from a normal donor by ultracentrifugation $(d$
$>1.030$ and $<1.050$ ) was used to calibrate the assay. The dilutions of the LDL to be assayed ranged from $1 / 40$ to $1 / 240$. All of them were run in duplicate, at least in two different dilutions.

Statistical analysis was performed using the mean paired Student's t-test and the Wilcoxon signed rank Test to compare differences between paired data. For evaluation of differences between means, in unpaired data, Wilcoxon rank sum test and Student's t-test were used. Correlation coefficients $(r)$ were determined by linear regression analysis. Statistical significance of the correlation coefficients was determined by the method of Fisher and Yates.

\section{Results}

Results for surface binding, internalization and degradation of LDL isolated from 13 diabetic patients before and after metabolic control are summarized in Table 1. There was no significant change in surface binding. A significantly lower internalization and intracellular degradation $(p<0.02)$ for the LDL isolated from diabetic patients before metabolic control was observed at all concentrations studied.

Since LDL isolated from patients before metabolic control were stored longer than those obtained after metabolic control, we examined the effect of LDL storage on LDL binding, internalization and degradation by fibroblasts. LDL of four normal volunteers were isolated from two separate blood collections 6-9 days apart. LDL prepared from the first collections were stored under the same conditions as the patient pre-control LDL samples. No differences between the metabolism of stored and fresh LDL isolated from normal subjects were found. To examine further the effect of LDL storage on LDL metabolism, we compared the differences observed in degradation between pre- and post-control LDL with the length of hospitalization time. No significant correlation was found $(r=0.14)$. 
In Figure 1 the mean changes in LDL surface binding, internalization and degradation between pre- and post-control LDL, isolated from diabetic subjects, and between stored and fresh LDL isolated from normal subjects are represented for $10 \mu \mathrm{g}$ $\mathrm{LDL} / \mathrm{ml}$ medium. A statistically significant increase in internalization and degradation was found in the post-control LDL from diabetic patients.

The difference in the handling of pre- and postcontrol LDL was observed in nine of the 13 diabetic patients studied. Two of the four patients who failed to show a difference were admitted in fair control

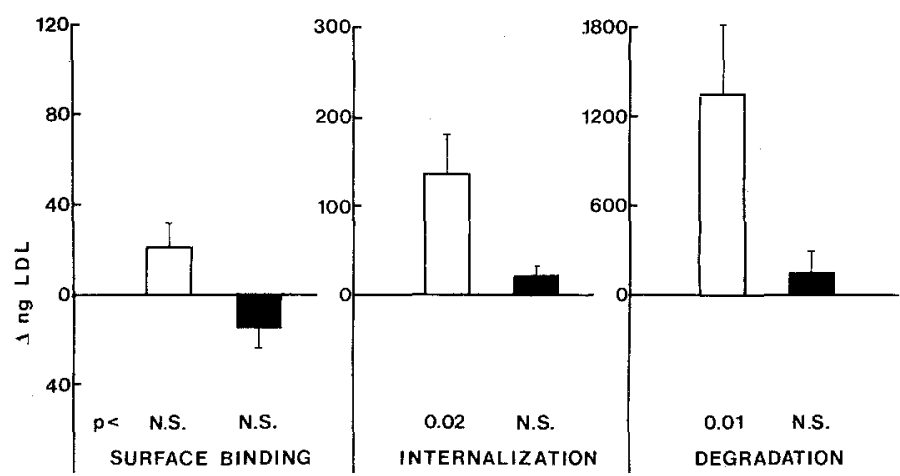

Fig. 1. Differences of surface binding, internalization and degradation of LDL isolated from 13 diabetic patients before and after metabolic control and of LDL isolated from two different plasma samples collected from four normal subjects with 6-9 day intervals between bleeds. The differences are expressed as mean \pm SEM for a concentration of $10 \mu \mathrm{g} \mathrm{LDL} / \mathrm{ml}$ of medium. The absolute levels of the three parameters studied were adjusted to $\mathrm{ng} \mathrm{LDL} / \mathrm{mg}$ cell protein, as described in Methods. $\square=$ diabetic patients (post-control LDL minus pre-control LDL); $\boldsymbol{\square}=$ normal subjects (fresh LDL minus stored LDL); NS = not significant
$\left(\mathrm{HbA}_{1 \mathrm{c}} 11.5 \%\right.$ and $11 \%$; plasma glucose 10.38 and $13.04 \mathrm{mmol} / 1$ ). The other two patients, admitted in poor control, showed a slightly increased degradation but failed to show increased internalization. The mean concentrations of total LDL and VLDL plasma cholesterol, total plasma triglycerides, plasma glucose and $\mathrm{HbA}_{1 \mathrm{c}}$ are represented in Table 2, for all patients and normal subjects studied.

To evaluate the effect of control in the handling of pre- and post-control LDL by fibroblasts, we compared the differences in $\mathrm{HbA}_{1 \mathrm{c}}$ and glucose observed in each patient with the differences observed in the degradation of pre- and post-control LDL. A significant correlation was obtained $(r=0.558, p<0.05$ for $\mathrm{HbA}_{1 \mathrm{c}}$ and $r=0.559, p<0.05$ for glucose). Furthermore, we compared the differences in the plasma LDL cholesterol obtained in each patient before and after metabolic control with the differences observed in the degradation of pre- and post-control LDL isolated from the same patient and we found a significant correlation $(r=0.586, p<0.05)$.

To compare the binding, internalization and degradation of patient-derived LDL with that obtained from normal subjects, LDL from seven of the 16 diabetic patients were studied simultaneously with LDL from seven sex- and age-matched control subjects. The results are summarized in Table 3. LDL isolated from normal subjects were degraded by fibroblasts to a greater extent $(p<0.05)$ than those obtained from diabetic patients before metabolic control. The degradation of the LDL isolated from the normal subjects was similar to that of LDL obtained from diabetic patients after metabolic control. In order to determine the influence of culture conditions, leading to

Table 2. Plasma lipid an lipoproteins, glucose and $\mathrm{HbA}_{1 \mathrm{c}}$ levels in normal and diabetic subjects before and after metabolic control

\begin{tabular}{|c|c|c|c|c|c|c|}
\hline & $\begin{array}{l}\text { Total } \\
\text { cholesterol } \\
(\mathrm{mmol} / \mathrm{l})\end{array}$ & $\begin{array}{l}\text { LDL- } \\
\text { cholesterol } \\
(\mathrm{mmol} / \mathrm{l})\end{array}$ & $\begin{array}{l}\text { VLDL- } \\
\text { cholesterol } \\
(\mathrm{mmol} / \mathrm{l})\end{array}$ & $\begin{array}{l}\text { Triglycerides } \\
(\mathrm{mmol} / \mathrm{l})\end{array}$ & $\begin{array}{l}\text { Plasma } \\
\text { glucose } \\
(\mathrm{mmol} / \mathrm{l})\end{array}$ & $\begin{array}{l}\mathrm{HbA}_{1 c} \\
(\% \text { of total } \\
\mathrm{HbA})\end{array}$ \\
\hline \multicolumn{7}{|l|}{ 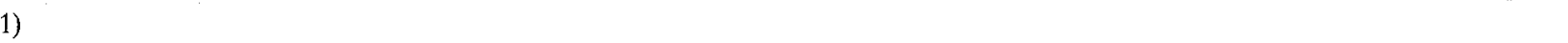 } \\
\hline $\begin{array}{l}\text { Diabetic patients } \\
\text { before control } \\
(n=16)\end{array}$ & $\begin{array}{l}5.98 \pm 1.86 \\
(231 \pm 72)^{a}\end{array}$ & $\begin{array}{l}3.36 \pm 0.93 \\
(130 \pm 36)^{\mathrm{a}}\end{array}$ & $\begin{array}{l}1.68 \pm 1.42 \\
(65 \pm 55)^{\mathrm{a}}\end{array}$ & $\begin{array}{l}3.29 \pm 2.11 \\
(291 \pm 187)^{\mathrm{a}}\end{array}$ & $\begin{array}{l}20.6 \pm 7.94 \\
(372 \pm 143)^{\mathrm{a}}\end{array}$ & $16.0 \pm 3.5$ \\
\hline \multicolumn{7}{|l|}{ 2) } \\
\hline $\begin{array}{l}\text { Diabetic patients } \\
\text { after control } \\
(n=13)\end{array}$ & $\begin{array}{l}4.27 \pm 0.83 \\
(165 \pm 32)\end{array}$ & $\begin{array}{l}2.77 \pm 0.65 \\
(107 \pm 25)\end{array}$ & $\begin{array}{l}0.47 \pm 0.36 \\
(18 \pm 14)\end{array}$ & $\begin{array}{l}0.89 \pm 0.47 \\
(79 \pm 42)\end{array}$ & $\begin{array}{l}6.11 \pm 2.66 \\
(110 \pm 48)\end{array}$ & $11.4 \pm 2.7$ \\
\hline \multicolumn{7}{|l|}{ 3) } \\
\hline $\begin{array}{l}\text { Normal subjects } \\
(n=11)\end{array}$ & $\begin{array}{l}4.04 \pm 0.72 \\
(156 \pm 28)\end{array}$ & $\begin{array}{l}2.35 \pm 0.67 \\
(91 \pm 26)\end{array}$ & $\begin{array}{l}0.41 \pm 0.28 \\
(16 \pm 11)\end{array}$ & $\begin{array}{l}0.87 \pm 0.38 \\
(77 \pm 34)\end{array}$ & $\begin{array}{l}4.27 \pm 0.67 \\
(77 \pm 12)\end{array}$ & $5.0 \pm 0.3$ \\
\hline$p$ value (1 versus 2 ) & $<0.01$ & $\mathrm{NS}^{\mathrm{b}}$ & $<0.01$ & $<0.01$ & $<0.001$ & $<0.01$ \\
\hline$p$ value (1 versus 3 ) & $<0.001$ & $<0.01$ & $<0.01$ & $<0.01$ & $<0.001$ & $<0.001$ \\
\hline
\end{tabular}

Results expressed as mean $\pm \mathrm{SD} ; \mathrm{NS}=$ not significant

a Levels in parentheses expressed in $\mathrm{mg} / \mathrm{dl}$. ${ }^{\mathrm{b}} p<0.05$ when comparing the levels obtained in diabetic patients before and after metabolic $\operatorname{control}(n=13)$ 
Table 3. Binding, internalization and degradation by normal fibroblasts of LDL isolated from seven diabetic patients and from seven ageand sex-matched control subjects

\begin{tabular}{|c|c|c|c|}
\hline & $\begin{array}{l}\text { Diabetic patients } \\
\text { before control }\end{array}$ & $\begin{array}{l}\text { Diabetic patients } \\
\text { after control }^{\mathrm{a}}\end{array}$ & Normal subjects \\
\hline \multicolumn{4}{|l|}{$\begin{array}{l}\text { Binding } \\
\text { (ng LDL/mg cell protein) }\end{array}$} \\
\hline $10 \mu \mathrm{g} \mathrm{LDL} / \mathrm{ml}$ medium & $142 \pm \quad 45$ & $171 \pm 71$ & $151 \pm 38$ \\
\hline $40 \mu \mathrm{g} \mathrm{LDL} / \mathrm{ml}$ medium & $315 \pm 100$ & $418 \pm 161$ & $367 \pm 143$ \\
\hline \multicolumn{4}{|l|}{$\begin{array}{l}\text { Internalization } \\
\text { (ng LDL/mg cell protein) }\end{array}$} \\
\hline $10 \mu \mathrm{g} \mathrm{LDL} / \mathrm{ml}$ medium & $747 \pm 214$ & $891 \pm 188$ & $869 \pm 132$ \\
\hline $40 \mu \mathrm{g} \mathrm{LDL} / \mathrm{ml}$ medium & $1706 \pm 461$ & $2122 \pm 510$ & $2011 \pm 225$ \\
\hline \multicolumn{4}{|l|}{$\begin{array}{l}\text { Degradation } \\
\text { (ng LDL/mg cell protein) }\end{array}$} \\
\hline $10 \mu \mathrm{g} \mathrm{LDL} / \mathrm{ml}$ medium & $3488 \pm 1429^{b}$ & $4988 \pm 919$ & $5402 \pm 1379$ \\
\hline $40 \mu \mathrm{g} \mathrm{LDL} / \mathrm{ml}$ medium & $7575 \pm 2784^{b}$ & $10,172 \pm 1540$ & $10,883 \pm 2399$ \\
\hline
\end{tabular}

Results expressed as mean $\pm \mathrm{SD}$

${ }^{a}$ Six patients only. ${ }^{\mathrm{b}} p<0.05$ compared with normal control subjects

Table 4. Relative cholesterol (free and total), triglyceride and protein composition of LDL isolated from diabetic subjects before and after metabolic control and from normal subjects

\begin{tabular}{|c|c|c|c|c|}
\hline & $\begin{array}{l}\text { Cholesterol/ } \\
\text { protein }\end{array}$ & $\begin{array}{l}\text { Triglyceride/ } \\
\text { protein }\end{array}$ & $\begin{array}{l}\text { Cholesterol/ } \\
\text { triglyceride }\end{array}$ & $\begin{array}{l}\text { Free/total } \\
\text { cholesterol }^{\mathrm{a}}\end{array}$ \\
\hline $\begin{array}{l}\text { Diabetic patients before metabolic } \\
\text { control } \\
(\mathrm{n}=11)\end{array}$ & $1.56 \pm 0.57$ & $0.52 \pm 0.23^{b}$ & $4.04 \pm 3.60$ & $0.23 \pm 0.03$ \\
\hline $\begin{array}{l}\text { Diabetic patients after metabolic } \\
\text { control } \\
(\mathrm{n}=11)\end{array}$ & $1.61 \pm 0.33$ & $0.34 \pm 0.13$ & $5.34 \pm 1.65$ & $0.26 \pm 0.05$ \\
\hline $\begin{array}{l}\text { Normal subjects } \\
(\mathrm{n}=8)\end{array}$ & $1.64 \pm 0.23$ & $0.29 \pm 0.06$ & $6.16 \pm 2.31$ & $0.24 \pm 0.08$ \\
\hline
\end{tabular}

Results expressed as mean $\pm \mathrm{SD}$

${ }^{a}$ From five to eight subjects in each group. ${ }^{\mathrm{b}} \mathrm{p}<0.05$ compared with diabetic patients after control and normal subjects

up- or down-regulation of LDL receptors, we studied, under both sets of conditions, two diabetic patients in poor metabolic control and two sex-and age-matched normal subjects. The studies were performed using 10 and $40 \mu \mathrm{g}$ of $\mathrm{LDL} / \mathrm{ml}$ of medium. In both sets of culture conditions, at the two concentrations studied, we found that the LDL isolated from the poorly controlled diabetic patient was less degraded by fibroblasts than that isolated from the matched normal control.

In order to determine whether changes in LDL lipid composition contributed to the results observed, we measured cholesterol, triglycerides and total protein in the pre- and post-control LDL isolated from 11 of the 16 hospitalized patients studied and in eight of the 11 normal control subjects from whom enough LDL was available (Table 4). The ratio between free and total cholesterol was determined in the LDL isolated from eight patients in poor metabolic control; five patients in good metabolic control and six normal subjects (Table 4). A significant decrease of the LDL triglyceride/protein ratio $(p<0.05)$ was observed in the post-control LDL. To evaluate further possible alterations of the LDL composition, we compared total LDL-protein and LDL-apolipoprotein B concentrations in LDL isolated from six patients in poor metabolic control, five in good metabolic control, and five normal subjects. The apolipoprotein $\mathrm{B}$ content was $97.8 \pm 3.4 \%, 98 . \pm 3.3 \%$ and $98.1 \pm 4.6 \%$ of the total LDL protein levels (mean $\pm \mathrm{SD}$ ), respectively in the normal subjects and in the patients in good and poor metabolic control.

\section{Discussion}

Our results indicate that normal fibroblasts showed decreased uptake and intracellular degradation of LDL isolated from diabetic patients in poor metabolic control. The differences observed were probably not related to $\mathrm{LDL}$ aging since storage of LDL from normal control subjects did not affect uptake or 
degradation. There was also no relationship between degradation and the length of patient hospitalization.

These differences were consistent in 9 of 13 patients studied. The other four did not follow the general trend. Two of these latter patients were hospitalized in fair control which may have explained the negative results. The other two patients showed some increase in degradation but not internalization. To support further the role of metabolic control in our findings, a significant correlation was found between the differences in $\mathrm{HbA}_{1 \mathrm{c}}$ and glucose and the differences in the degradation of pre- and post-control LDL.

Our results also show that the degradation of $\mathrm{LDL}$ isolated from age- and sex-matched normal subjects is similar to that isolated from diabetic patients in good metabolic control. In contrast, degradation of LDL from normal subjects is significantly higher than that obtained with LDL isolated from diabetics in poor control. A similar finding was observed when two patients in poor metabolic control and two sexand age-matched normal subjects were studied under culture conditions that led to down-regulation of LDL receptors. The latter experiment was performed since it was more likely to reproduce the conditions encountered by the peripheral cells in vivo.

These results suggest a possible mechanism for enhanced atherosclerosis in diabetic patients. As postulated by Goldstein and Brown [2], the LDL pathway protects against atherosclerosis, allowing cells to take up LDL to satisfy cholesterol needs and to maintain plasma LDL concentrations below threshold levels for atherosclerosis. In diabetics, no abnormalities in the LDL pathway have been shown to date [3] but in this study, we demonstrate that there is a significant decrease of internalization and catabolism of the LDL isolated from diabetic patients in poor control. The decrease in the internalization and catabolism of pre-control LDL is not due to alterations in the number of cell receptors since we used the same pool of normal human fibroblasts in all our experiments. It is most probably due to alterations in LDL composition.

Whatever the mechanism might be, this decrease could eventually lead to plasma LDL concentrations that exceed the threshold levels for atherosclerosis. In support of this concept, we found that the degree of impairment of degradation of the LDL isolated from diabetic subjects in poor control was related to a rise in plasma LDL-cholesterol levels.

As we mentioned before, the differences observed in LDL behaviour are likely to be due to alterations in LDL composition. These alterations might be in LDL lipid composition, LDL apoprotein composition and/or in the carbohydrate moiety of apolipoprotein LDL. The lipid composition of LDL isolated from diabetic patients has been studied previously by Schonfeld et al. [18] who reported an increased triglyceride content of LDL. In our present studies we found similar alterations in the composition of LDL isolated from diabetic patients before metabolic control. Since the pre-control LDL were less internalized and degraded by fibroblasts than those isolated from the same patients after metabolic control, a logical conclusion would be that the significant increase of the triglyceride content of LDL that we observed can interfere with its metabolic behaviour. It has been postulated that the triglyceride content of LDL may greatly influence the fluidity of the lipid core of the particle [19]. However, it is not clear that this would affect LDL metabolism by fibroblasts. Whether the alteration in the triglyceride/protein ratio is the main or only factor determining the metabolic properties of diabetic LDL, cannot be concluded from our experiments. Further studies of LDL lipid composition are needed. In particular, phospholipids must be quantitated, since they are major lipid constituents of the LDL surface. According to Steinberg [20], the apoprotein-phospholipid interaction confers the specificity for LDL to be recognized by the cell.

Alterations in LDL apoprotein composition could also explain these changes in LDL behaviour. The LDL protein consists mainly of apolipoprotein $\mathrm{B}$, but also contains small amounts of apolipoprotein C [21]. Havel [22] has shown that when the content of the $\mathrm{C}$ apoproteins is increased in VLDL and chylomicrons, their uptake by perfused livers is inhibited. In order to explore indirectly the possibility that a similar phenomenon may occur in LDL, we determined the apolipoprotein B content of LDL and related that with the LDL total protein content. No differences existed between patients in poor and good metabolic control and normal subjects.

Finally, differences in the carbohydrate moiety of LDL could also explain the alterations in LDL behaviour. Morell et al. [23] postulated that one of the roles of the carbohydrate portion of glycoproteins is the regulation of protein catabolism. Studies on the function of the carbohydrate moiety of apolipoprotein LDL have been carried out. Shireman and Fisher [24] found no differences in the uptake of LDL when its carbohydrate moiety was removed completely. In this study, no reference to changes in LDL charge was made and catabolism was not studied. Other authors found significant differences in LDL internalization and clearance after removal of sialic acid radicals from native LDL [25]. The removal of sialic acid led to alterations in LDL charge.

Non-enzymatic glycosylation of Apo B, secondary to hyperglycaemia, could also lead to alterations of LDL behaviour. Non-enzymatic glycosylation of 
several proteins have been described in diabetes [26] and some differences in behaviour of glycosylated proteins have been found including decreased solubility and greater aggregability [27]. Furthermore, Witztum et al. [28] recently found that LDL glycosylated in vitro was less degraded by fibroblasts than normal LDL.

The precise mechanisms of altered LDL-cell kinetics in diabetes mellitus are unknown and await further studies. However, the present study represents the first observation that metabolic control in diabetes mellitus can alter LDL-cell interaction and may have relevance to the problems of atherosclerosis in diabetic patients.

Acknowledgement. We thank Dr. M.G. Buse, Medical University of South Carolina and Dr. R.S. Lees, Massachusetts Institute of Technology for their encouragement and valuable discussions on various aspects of this work. We are grateful to the staff of the Specialized Diagnostic and Therapeutic Unit, Charleston V.A. Medical Center and the General Clinical Research Center, Medical University of South Carolina for their expert assistance in the patient studies. We also thank Ms. B. Malenkos and Mr. L. Long for their excellent technical assistance and Ms. J. Brandon for secretarial help. This work is supported in part by the V.A. Medical Center, the General Clinical Research Center of the Medical University of South Carolina (Grant No. RR-01070) and the South Carolina Appropriation for Biomedical Research. Dr. Lopes-Virella is the recipient of a Special Emphasis Research Career Development Award (SERCA) from the NHLBI-NIAMDD, NIH (1-KO1AM00591-03). Dr. Mayfield is the recipient of a Special Emphasis Research Career Development Award (SERCA) from the NHLBINIAMDD, NIH. (1-K01-AM00892-01).

\section{References}

1. Garcia MJ, McNamara PM, Gordon T, Kannel WB (1974) Morbidity and mortality in diabetics in the Framingham population-sixteen year follow-up study. Diabetes 23: 105-111

2. Goldstein JL, Brown MS (1977) The low density lipoprotein pathway and its relation to atherosclerosis. Ann Rev Biochem 46:897-930

3. Chait A, Bierman EL, Albers JJ (1979) Low density lipoprotein receptor activity in fibroblasts cultured from diabetic donors. Diabetes 28:914-918

4. Sherer GK, Fitzharris TP, Faulk WP, LeRoy EC (1980) Cultivation of microvascular endothelial cells from human preputial skin. In Vitro 16: 675-684

5. Radding CM, Steinberg D (1960) Studies on the synthesis and secretion of serum lipoproteins by rat liver slices. J Clin Invest 39: 1560-1568

6. Lopes-Virella MF, Virella G, Parreira F, Sequerra-Amram S (1974) Comparative analysis of some techniques for the elctrophoretic separation of serum lipoproteins. Rev Clin Esp 133: 195-204

7. Bratzler RL, Chisolm GM, Colton CK, Smith JA, Lees RS (1977) The distribution of labelled low density lipoproteins across the rabbit thoracic aorta in vivo. Atherosclerosis 28: 289-307

8. Folch J, Lees M, Stanley GHS (1957) A simple method for the isolation and purification of total lipids from animal tissues. $\mathrm{J}$ Biol Chem 226: 497-509

9. Brown MS, Dana SE, Goldstein JL (1974) Regulation of 3-hy- droxy-3-methyl glutaryl coenzyme A reductase activity in cultured human fibroblasts. J Biol Chem 249:789-796

10. Bierman EL, Stein O, Stein Y (1974) Lipoprotein uptake and metabolism by rat aortic smooth muscle cells in tissue culture. Circ Res 35: 136-150

11. Lowry OH, Rosebrough NJ, Farr AL, Randall BJ (1951) Protein measurement with the Folin phenol reagent. J Biol Chem 193:265-275

12. Kadish AH, Little RL, Steinberg JC (1968) A new and rapid method for the determination of glucose by measurement of rate of oxygen consumption. Clin Chem 14: 116-131

13. Spicer KN, Allen RC, Buse MG (1978) A simplified assay of hemoglobin $A_{1 \mathrm{c}}$ in diabetic patients, using isoelectric focusing and quantitative microdensitometry. Diabetes $27: 384-388$

14. Manual of lipid operations (1974) Lipid research clinics program, vol. I. Lipid and Lipoprotein Analysis, Department of Health, Education and Welfare, Publ No (NIH) 75-628

15. Ishikawa TT, MacGee J, Morrison JA, Glueck CJ (1974) Quantitative analysis of cholesterol in 5 to $20 \mu \mathrm{l}$ of plasma. J Lipid Res 15: 286-291

16. Laurell CB (1966) Quantitative estimation of protein by electrophoresis in agarose gel containing antibodies. Anal Biochem 15: $45-52$

17. Lopes-Virella MF, Virella G, Evans G, Malenkos SB, Colwell JA (1980) Immunonephelometric assay of human apolipoprotein AI. Clin Chem 26:1205-1208

18. Schonfeld G, Birge E, Miller JP, Kessler G, Santiago J (1974) Apoprotein B levels and altered lipoprotein composition in diabetes. Diabetes 23: 827-834

19. Deckelbaum RJ, Shipley GG, Small DM (1977) Structure and interactions of lipids in human plasma low density lipoproteins. J Biol Chem 252: 744-754

20. Steinberg D (1980) LDL cell interaction in vivo and in vitro. Ann NY Acad Sci 348: 256-262

21. Eisenberg S, Levy RI (1975) Lipoprotein metabolism. Adv Lipid Res 13: 1-89

22. Havel RJ (1980) Lipoprotein biosynthesis and metabolism. Ann NY Acad Sci 348: 16-27

23. Morell AG, Gregoriadis G, Schlinberg IH, Hickman J, Ashwell $\mathrm{G}$ (1971) The role of sialic acid in determining the survival of glycoproteins in the circulation. J Biol Chem 246: 1461-1467

24. Shireman RB, Fisher WR (1979) The absence of a role for the carbohydrate moeity in the binding of apolipoprotein $B$ to the low density lipoprotein receptor. Biochim Biophys Acta 572: 537-540

25. Malmendier CL, Feremans WW, Fontaine M (1979) The effect of sialic acid removal on very low density lipoprotein. Artery 6: 144-156

26. Bunn HF, Gabbay KH, Gallop PM (1978) The glycosylation of hemoglobin: relevance to diabetes mellitus. Science 200:21-27

27. McFarland KF, Catalano EW, Day JF, Thorpe SR, Baynes JW (1979) Non-enzymatic glycosylation of serum proteins in diabetes mellitus. Diabetes 28: 1011-1014

28. Witztum JL, Branks MJ, Steinberg D (1981) Nonenzymatic gly cosylation of low density lipoprotein (LDL) interferes with its high affinity receptor uptake by fibroblasts. Clin Res 29:61 (Abstract)

Received: 10 August 1981

and in revised form: 29 November 1981

Dr. M.F.Lopes-Virella

Department of Medicine

Endocrinology-Metabolism-Nutrition Division

Medical University of South Carolina

171 Ashley Avenue

Charleston 29403, USA 